\title{
PERANCANGAN SISTEM INFORMASI PENJUALAN PADA APOTEK
}

\author{
Angelina Permatasari \\ Computerized Accounting Department, School of Information Systems, Binus University \\ Jl. K.H. Syahdan No. 9, Palmerah, Jakarta Barat 11480 \\ angelina_psw@binus.ac.id
}

\begin{abstract}
The purpose of this study is to analyze the problems on the sales system of a pharmacy, to identify the information needs and to design a sales information system that addresses the information needs. The methodologies used are analysis and design. Analysis are conducted to identify the needs of information through observation, interviews, and surveys of the old system. While the design method used is Object Oriented Analysis and Design (OOAD). This study results in an application design of sales information system for the pharmacy to handle the manual sales system. A computerized sales information system is able to solve problems that occur in the old system and procedures at the pharmacy.
\end{abstract}

Keywords: design, sales information system

\begin{abstract}
ABSTRAK
Tujuan penelitian ini adalah untuk menganalisis masalah-masalah pada sistem penjualan sebuah apotek, mengidentifikasi kebutuhan informasi dan merancang sistem informasi penjualan yang mampu menjawab kebutuhan informasi tersebut. Metodologi yang digunakan adalah metode analisis dan metode perancangan. Analisis dilakukan untuk mengidentifikasi kebutuhan informasi melalui observasi, wawancara, dan survey terhadap sistem lama. Sedangkan metode perancangan yang digunakan adalah Object Oriented Analysis and Design (OOAD). Hasil yang dicapai adalah sistem informasi penjualan bagi apotek dalam bentuk perancangan aplikasi untuk menangani sistem penjualan yang selama ini masih dilakukan secara manual. Sistem informasi penjualan yang terkomputerisasi dapat memecahkan masalah-masalah yang terjadi pada sistem dan prosedur yang lama pada apotek tersebut.
\end{abstract}

Kata kunci: perancangan, sistem informasi penjualan 


\section{PENDAHULUAN}

Sistem informasi adalah pengaturan orang, data, proses dan teknologi informasi yang berinteraksi untuk mengumpulkan, memproses, menyimpan dan menyediakan sebagai output informasi yang diperlukan untuk mendukung sebuah organisasi (Whitten, Bentley dan Ditman, 2004). Ketatnya persaingan yang ada di dunia bisnis membuat perusahaan dituntut untuk memiliki sistem informasi yang memadai, sebagai bagian dari strategi. Penerapan suatu sistem informasi akan membuat perusahaan mampu bersaing dengan para pesaing yang ada, karena penerapan suatu sistem informasi di perusahaan akan memberikan nilai lebih dan merupakan suatu keunggulan yang kompetetif bagi perusahaan yang menerapkannya.

Penjualan merupakan salah satu proses bisnis yang sangat penting bagi perusahaan. Penjualan adalah jumlah yang dibebankan kepada pelanggan untuk barang dagangan yang dijual, baik secara tunai maupun kredit (Warren, et al., 2005). Melalui penjualan, perusahaan akan menghasilkan profit yang optimal dalam jangka panjang. Oleh karena itu efektivitas dan efisiensi dari sistem informasi penjualan merupakan faktor yang sangat penting bagi perusahaan dalam mencapai visi dan misi dari perusahaan itu sendiri.

Menurut Laudon dan Laudon (2004), perancangan sistem adalah cara bagaimana sebuah sistem dapat memenuhi kebutuhan informasi yang telah ditentukan oleh analis sistem. Analisis sistem adalah penelitian atas sistem yang telah ada dengan tujuan untuk merancang sistem baru atau diperbaharui (McLeod dan Schell, 2001). Aktivitas-aktivitas dalam analis sistem menurut McLeod antara lain mengumumkan penelitian sistem, mengorganisasikan tim proyek, mendefinisikan kebutuhan informasi, mendefinisikan kriteria kinerja sistem, menyiapkan usulan rancangan, menyetujui atau menolak rancangan proyek (McLeod, 2001).

Studi kasus penelitian ini adalah apotek yang merupakan suatu usaha yang bergerak di bidang penjualan obat-obatan, baik obat bebas, obat keras, dan obat dengan menggunakan resep dokter. Tujuan dari penelitian ini adalah mengidentifikasi sejauh mana sistem informasi penjualan dapat bermanfaat bagi apotek dalam menunjang kegiatannya, menganalisis masalah yang ada pada sistem yang sedang berjalan dan merancang sistem informasi penjualan untuk menunjang setiap penjualan yang terjadi di apotek.

Manfaat dari penelitian ini adalah dapat mengetahui kekurangan dan kelemahan yang ada pada sistem yang sedang berjalan sehingga dapat diatasi sebelum mengakibatkan kesalahan perhitungan ataupun kesalahan dalam pelaporan, memastikan bahwa tidak ada perbedaan antara jumlah kas yang ada secara fisik dengan yang ada pada pencatatan, mempersingkat waktu pencarian akan data-data penjualan yang dibutuhkan, meningkatkan pengendalian internal dalam penjualan obat sehingga penelitian ini dapat berguna bagi apotek dalam meningkatkan efektifitas dan efisiensi dalam siklus penjualan.

\section{METODE}

Metode yang digunakan adalah sebagai berikut. Pertama, metode analisis yaitu studi pustaka, teknik observasi, survey terhadap sistem lama, analisis kebutuhan, identifikasi kebutuhan informasi, wawancara dan pembuatan rich picture dan event table dari sistem yang sedang berjalan. Kedua, metode perancangan menggunakan Object Oriented Analysis and Design (OOAD) yang dimulai dengan pembuatan overview activity diagram, entity relationship diagram, use case diagram, rancangan database, rancangan layar, rancangan laporan. 


\section{HASIL DAN PEMBAHASAN}

\section{Sistem yang Sedang Berjalan}

Untuk penjualan obat bebas, proses bisnisnya adalah sebagai berikut (Gambar 1). Pasien datang ke apotek membawa daftar obat yang ingin dibeli kepada karyawan non-farmasis. Karyawan farmasis memeriksa stok obat di gudang. Jika obat tersedia, karyawan farmasis akan mengambilkan obat bebas tersebut berdasarkan daftar obat dan diberikan kepada karyawan non-farmasis yang selanjutnya akan diberikan kepada pasien. Kasir membuatkan tagihan sebanyak dua rangkap. Rangkap pertama untuk pelanggan dan rangkap keduanya untuk diarsip. Setelah pelanggan membayar tagihan, karyawan farmasis akan meng-update catatan persediaan obat. Untuk lebih jelasnya, event dapat dilihat pada Tabel 1.

Sementara untuk penjualan obat keras dan yang dengan menggunakan resep dokter, proses bisnisnya adalah sebagai berikut (Gambar 2). Pasien datang ke apotek membawa resep dan disampaikan kepada karyawan non-farmasis. Resep diberi harga oleh karyawan farmasis dan diinformasikan kepada pelanggan. Kasir membuatkan tagihan sebanyak dua rangkap. Rangkap pertama untuk pelanggan dan rangkap keduanya untuk diarsip. Setelah pelanggan melakukan pembayaran, resep diberi nomor oleh kasir. Lalu dilakukan peracikan, pelabelan, dan pengemasan obat oleh karyawan farmasis berdasarkan resep yang telah diberi nomor oleh kasir. Setelah obat selesai, dilakukan cross-check atas obat oleh karyawan farmasis yang lain. Diberikan informasi mengenai obat dan penyerahan obat kepada pasien oleh karyawan farmasis. Selanjutnya karyawan non-farmasis akan memberikan Form Data Pelanggan untuk pendataan dan diarsipkan. Dilakukan update catatan persediaan obat oleh karyawan farmasis. Untuk lebih jelasnya, event dapat dilihat pada Tabel 2.

Setiap lima bulan sebelum tanggal kadaluarsa obat, karyawan farmasis akan menghubungi supplier untuk menukarkan obat tersebut dengan yang baru. Pada akhir bulan, karyawan farmasis dan non-farmasis akan melakukan stock opname dan kasir akan membuat laporan penjualan yang akan diberikan kepada manajer. Untuk hasil stock opname obat-obatan golongan narkotik, akan dilaporkan ke Dinas Kesehatan Kota.

\section{Analisis Temuan Survey}

Berdasarkan survei ditemukan: (1) pencatatan dan penyimpanan tagihan obat yang masih secara manual yang memungkinkan terjadinya nota hilang dan rusak; (2) terdapat perbedaan antara jumlah uang kas yang diterima dengan tagihan obat; (3) sering terjadinya kesalahan pencatatan pada tagihan obat, data pelanggan, dan dalam penomoran resep; (4) pencarian informasi akan dokumendokumen apotek yang kurang efisien yang menyebabkan waktu pencarian yang panjang.

\section{Alternatif Pemecahan Masalah}

Untuk mememcahkan masalah-masalah di atas, diusulkan untuk: (1) mengembangkan suatu Sistem Informasi Penjualan Apotek yang dapat mendukung setiap proses bisnis apotek; (2) menerapkan pencatatan data yang terkomputerisasi yaitu dengan menggunakan database.

\section{Perancangan Sistem}

Overview activity diagram (OAD) sistem informasi penjualan yang diusulkan dapat dilihat pada Gambar 3 dan 4. 


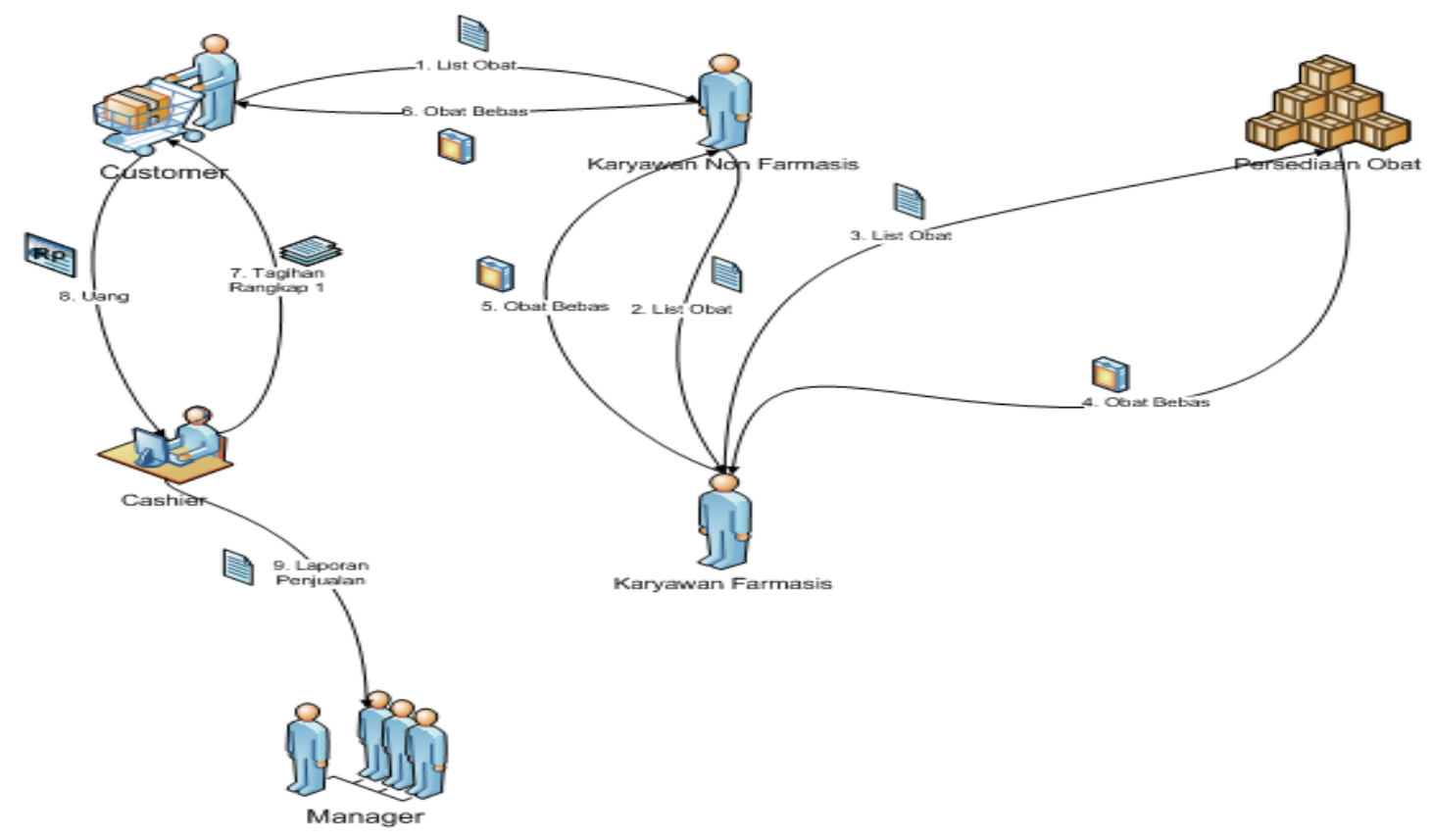

Gambar 1 Rich picture prosedur penjualan obat bebas.

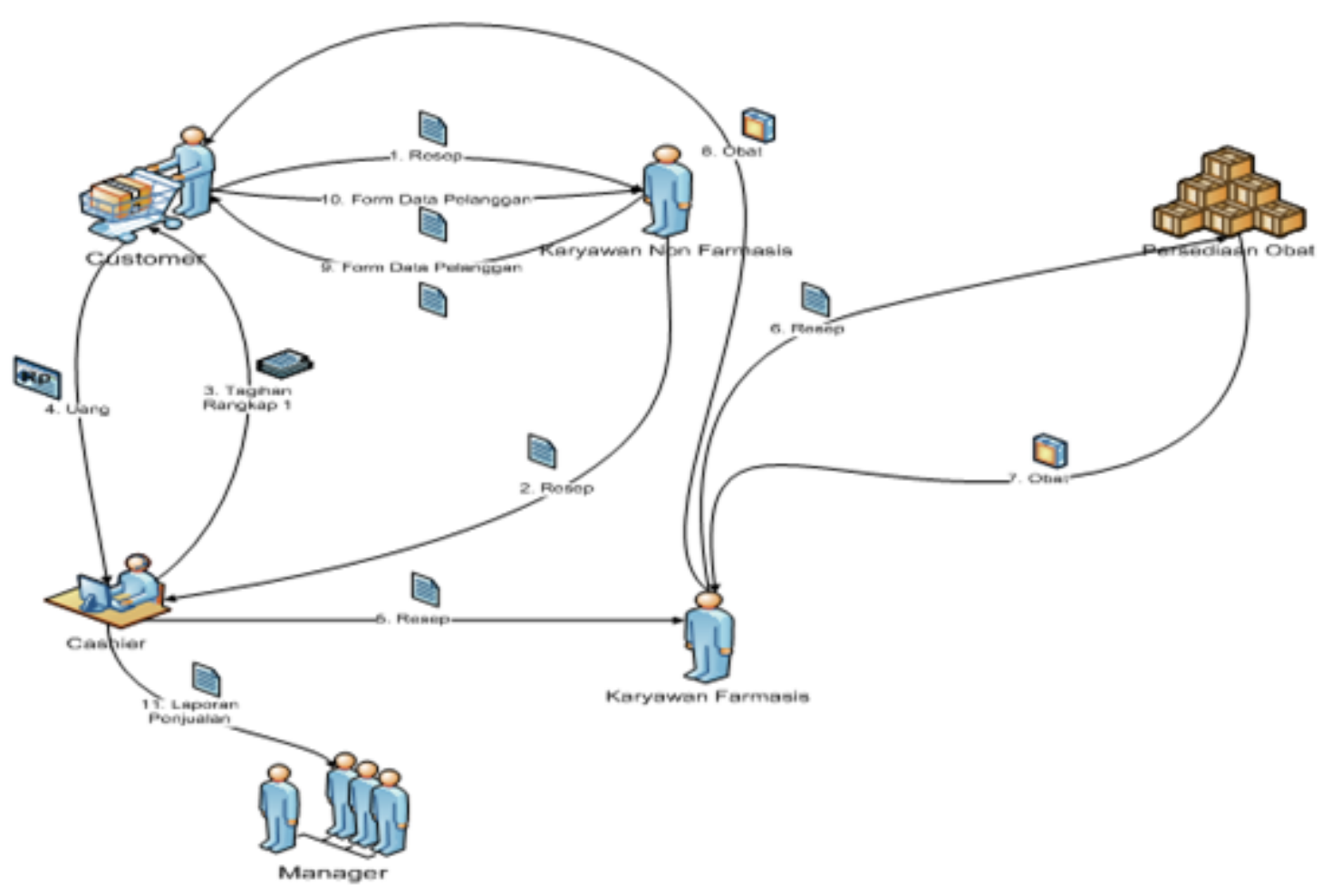

Gambar 2 Rich picture prosedur penjualan obat keras dan resep. 
Tabel 1 Event Table Prosedur Penjualan Obat Bebas

\begin{tabular}{|c|c|c|c|}
\hline Event & $\begin{array}{l}\text { Internal Agent } \\
\text { (Assuming } \\
\text { Responsibility) }\end{array}$ & Start When & Activity \\
\hline 1. Melayani Pelanggan & Karyawan Non Farmasis & $\begin{array}{l}\text { Pelanggan datang } \\
\text { meminta obat }\end{array}$ & - Menerima obat \\
\hline $\begin{array}{ll}\text { 2. } & \text { Memeriksa } \\
& \text { Persediaan Obat }\end{array}$ & Karyawan Farmasis & $\begin{array}{l}\text { Menerima list obat dari } \\
\text { Karyawan Non Farmasis }\end{array}$ & $\begin{array}{ll}\text { - } & \text { Memeriksa } \\
\text { ketersediaan obat } \\
\text { yang diminta } \\
\text { - Memberikan obat } \\
\text { yang diminta apabila } \\
\text { tersedia kepada } \\
\text { Karyawan Non } \\
\text { Farmasis }\end{array}$ \\
\hline 3. Menyerahkan Obat & Karyawan Non Farmasis & $\begin{array}{l}\text { Menerima obat dari } \\
\text { Karyawan Farmasis }\end{array}$ & $\begin{array}{l}\text { Memberika obat } \\
\text { yang diminta kepada } \\
\text { customer }\end{array}$ \\
\hline $\begin{array}{ll}\text { 4. } & \text { Menerima } \\
& \text { Pembayaran }\end{array}$ & Cashier & $\begin{array}{l}\text { Obat diterima oleh } \\
\text { Customer }\end{array}$ & $\begin{array}{ll}- & \text { Membuat tagihan } \\
\text { obat } \\
\text { - } & \text { Menerima uang dari } \\
& \text { Customer } \\
\end{array}$ \\
\hline 5. Membuat Laporan & Cashier & Akhir bulan & $\begin{array}{l}\text { - } \quad \text { Membuat laporan } \\
\text { penjualan } \\
\text { berdasarkan arsip } \\
\text { Tagihan Obat }\end{array}$ \\
\hline
\end{tabular}

Tabel 2 Event Table Prosedur Penjualan Obat Keras dan Resep

\begin{tabular}{|c|c|c|c|}
\hline Event & $\begin{array}{l}\text { Internal Agent } \\
\text { (Assuming } \\
\text { Responsibility) }\end{array}$ & Start When & Activity \\
\hline 1. Melayani Pelanggan & Karyawan Non Farmasis & $\begin{array}{l}\text { Pelanggan datang } \\
\text { menyerahkan resep }\end{array}$ & $\begin{array}{l}\text { - Mengambil resep } \\
\text { obat }\end{array}$ \\
\hline $\begin{array}{ll}\text { 2. } & \text { Memeriksa } \\
& \text { Persediaan Obat }\end{array}$ & Cashier & $\begin{array}{l}\text { Menerima resep dari } \\
\text { Karyawan Non Farmasis }\end{array}$ & $\begin{array}{ll}\text { - } & \text { Menomorkan resep } \\
\text { - } & \text { Membuat tagihan } \\
\text { obat/resep } \\
\text { - } & \text { Menerima uang dari } \\
& \text { Customer } \\
\end{array}$ \\
\hline 3. Menyerahkan Obat & Karyawan Farmasis & $\begin{array}{l}\text { Menerima resep yang } \\
\text { telah diberi nomor dari } \\
\text { Cashier }\end{array}$ & $\begin{array}{ll}\text { - } & \text { Meracik, memberi } \\
\text { label, dan } \\
\text { mengemas obat } \\
\text { - Memberikan obat } \\
\text { keras/obat hasil } \\
\text { racikan kepada } \\
\text { Customer }\end{array}$ \\
\hline $\begin{array}{ll}\text { 4. } & \text { Menerima } \\
& \text { Pembayaran }\end{array}$ & Karyawan Non Farmasis & $\begin{array}{l}\text { Obat diterima oleh } \\
\text { Customer }\end{array}$ & $\begin{array}{ll}\text { - } & \text { Memberikan Form } \\
\text { Data Pelanggan } \\
\text { kepada Customer } \\
\text { - } \quad \text { Menerima dan } \\
\text { Mengarsipkan Form } \\
\text { Data Pelanggan } \\
\text { yang telah diisi oleh } \\
\text { Customer }\end{array}$ \\
\hline
\end{tabular}




\begin{tabular}{|c|c|c|c|}
\hline 5. Membuat Laporan & Cashier & Akhir bulan & $\begin{array}{ll}\text { - } & \text { Membuat laporan } \\
\text { penjualan } \\
\text { berdasarkan arsip } \\
\text { Tagihan Obat }\end{array}$ \\
\hline
\end{tabular}

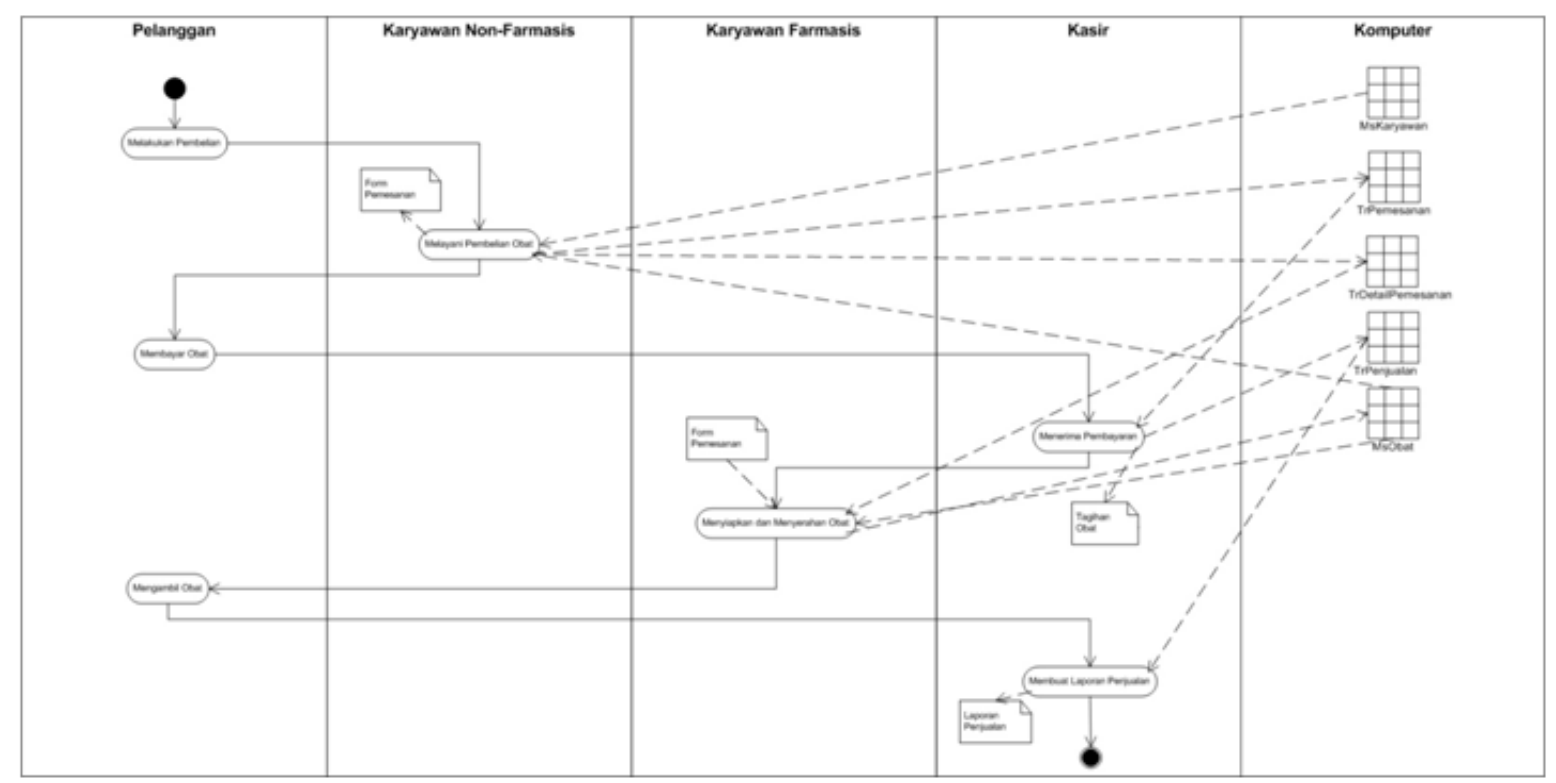

Gambar 3 OAD prosedur penjualan obat bebas.

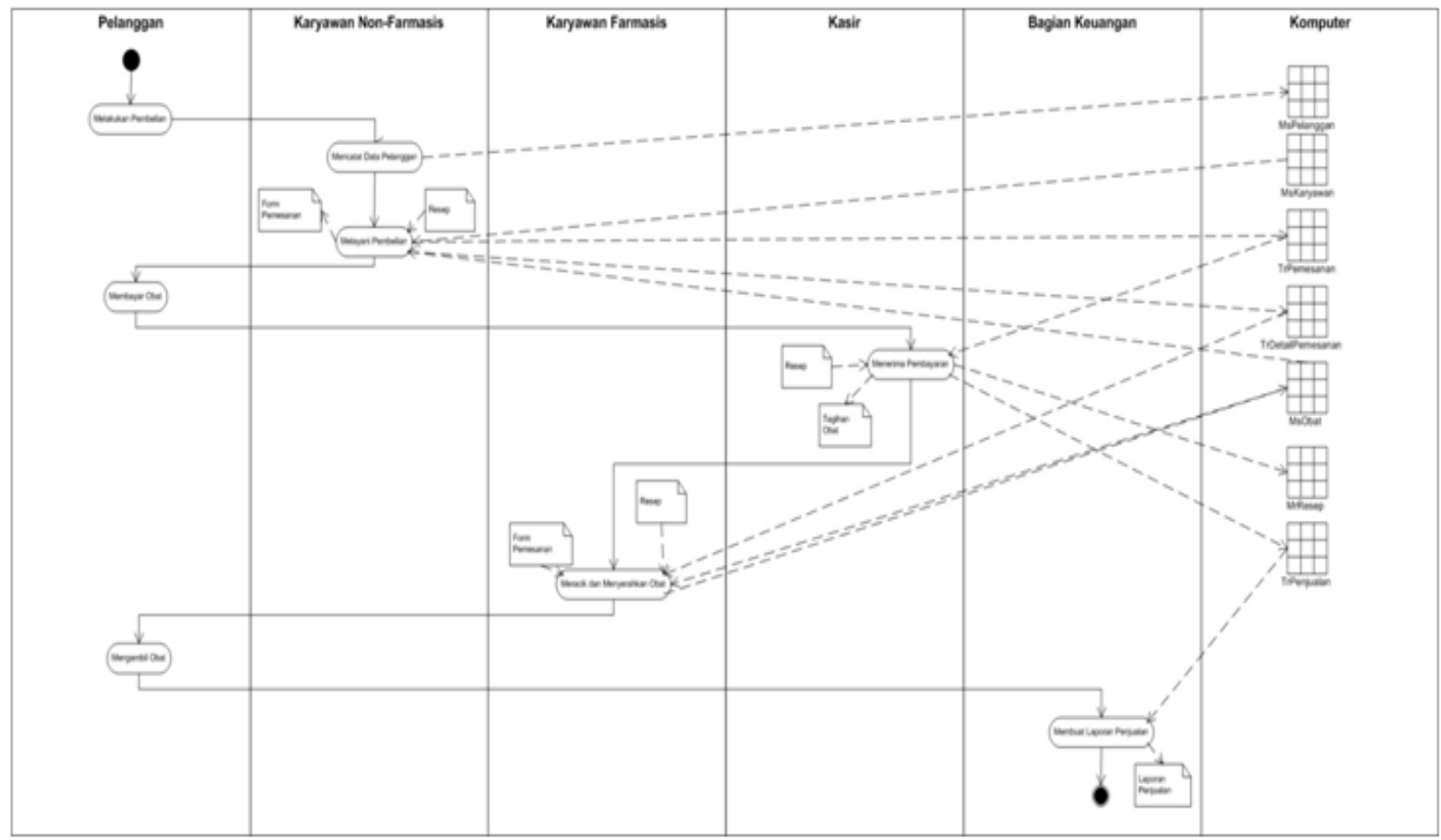

Gambar 6 OAD prosedur penjualan obat keras dan resep. 
Entity relationship diagram untuk sistem yang diusulkan adalah (Gambar 5). Use case diagram sistem informasi penjualan yang diusulkan ditampilkan pada Gambar 6 dan 7.

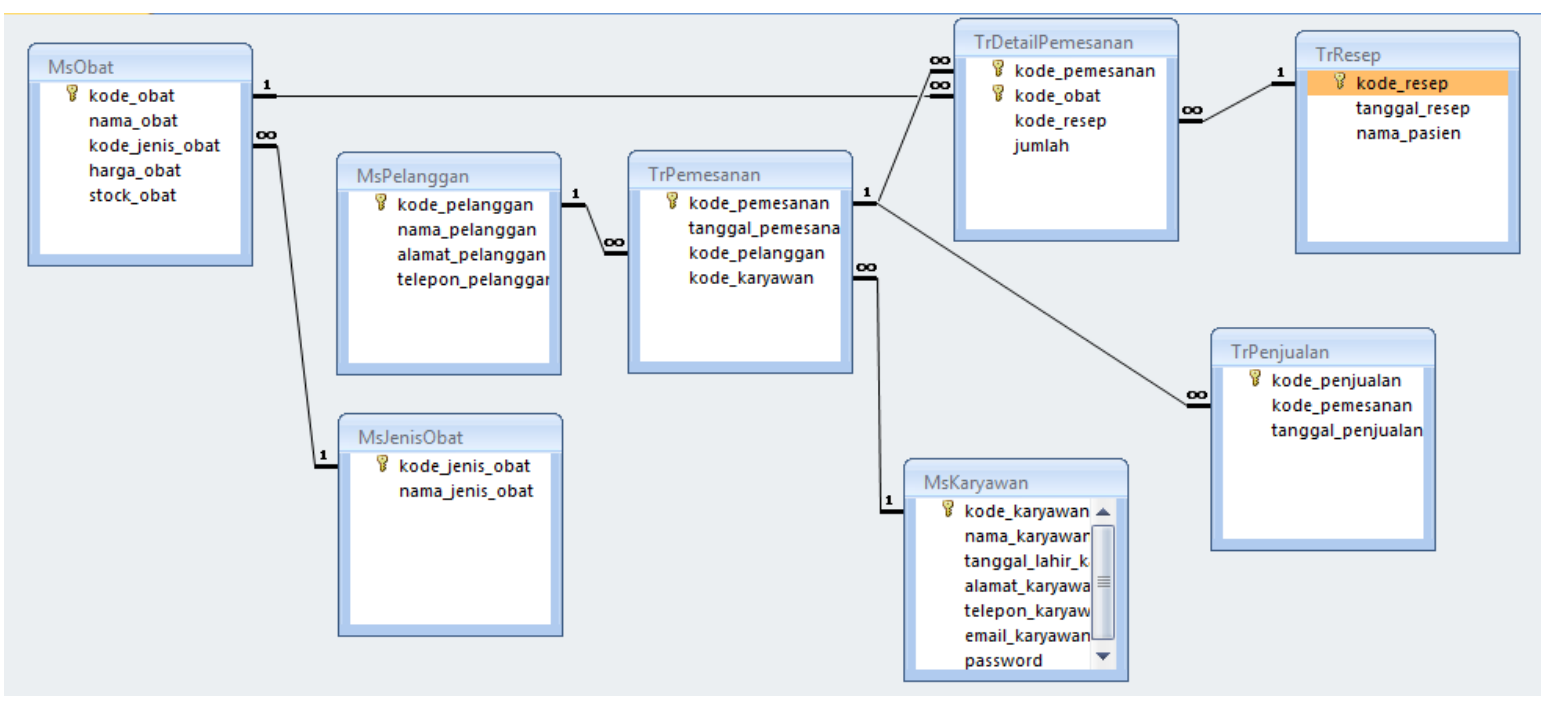

Gambar 5 Entity relationship diagram sistem informasi penjualan yang diusulkan.

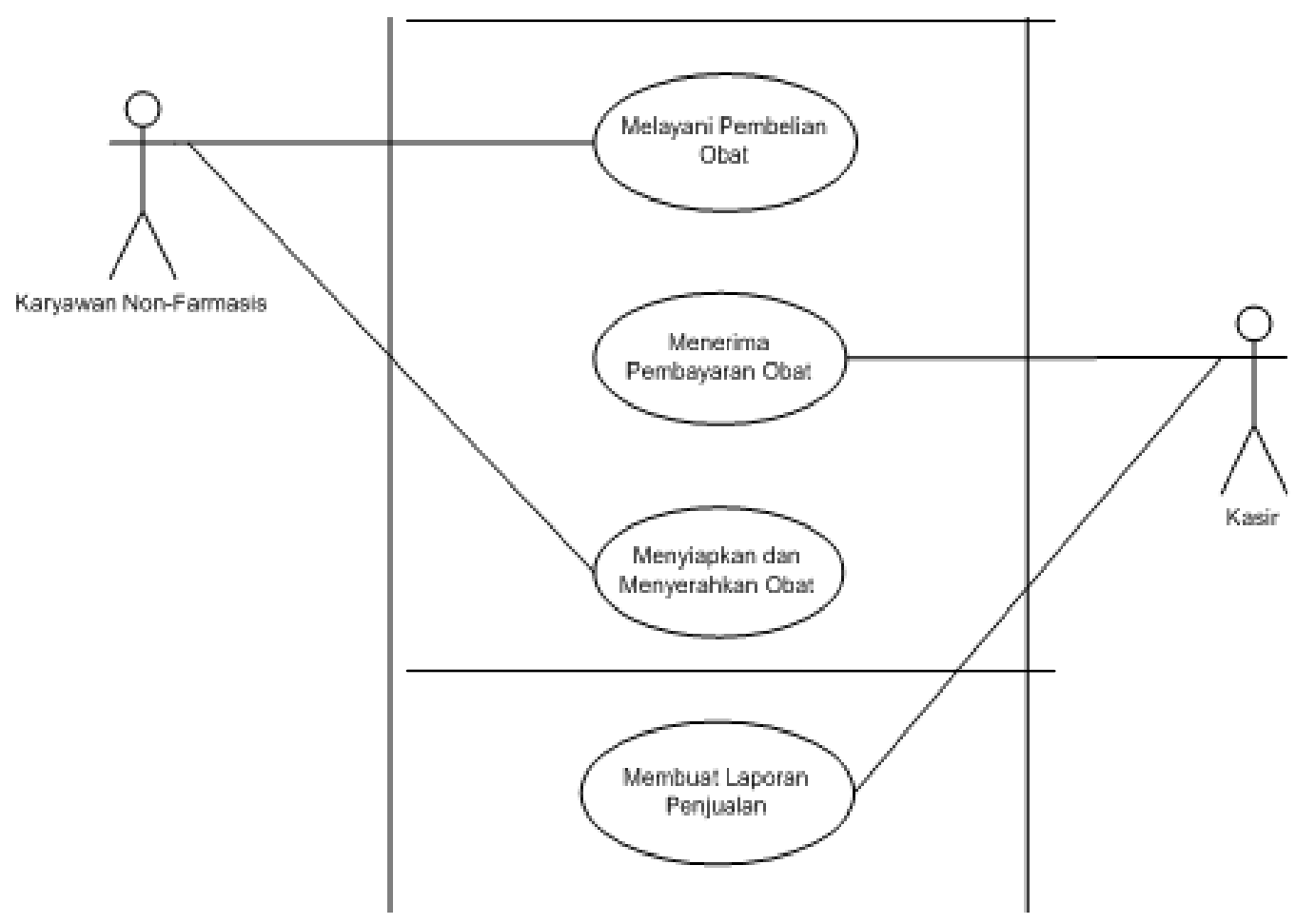

Gambar 6 Use case diagram sistem informasi penjualan obat bebas yang diusulkan. 


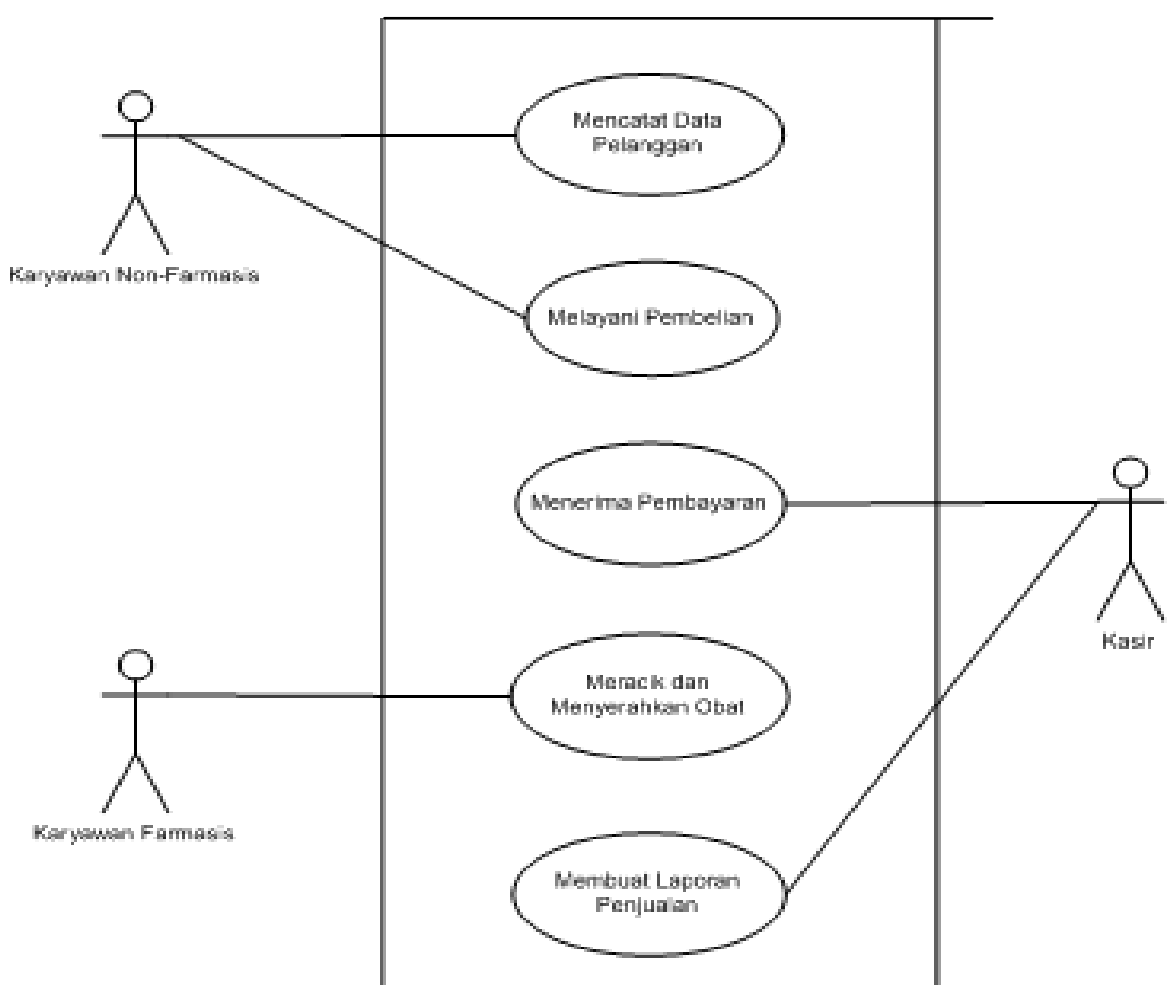

Gambar 7 Use case diagram sistem informasi penjualan obat keras dan resep yang diusulkan.

Rancangan Database sebagai berikut:

$\begin{array}{ll}\text { Table Name } & \text { MsObat } \\ \text { Primary Key } & =\text { kode_obat }\end{array}$

\begin{tabular}{llll}
\multicolumn{1}{c}{ Field Name } & \multicolumn{1}{c}{ Data Type } & \multicolumn{1}{c}{ Field Size } & \multicolumn{1}{c}{ Keterangan } \\
\hline kode_obat & Text & 5 & Kode Obat \\
\hline nama_obat & Text & 100 & Nama Obat \\
\hline kode_jenis_obat & Text & 5 & Kode Jenis Obat \\
\hline harga_obat & Number & Long Integer & Harga Obat \\
\hline stock_obat & Number & Long Integer & Stock Obat \\
\hline
\end{tabular}

Table Name = MsJenisObat

Primary Key = kode_jenis_obat

\begin{tabular}{|c|c|c|c|}
\hline Field Name & Data Type & Field Size & Keterangan \\
\hline kode_jenis_obat & Text & 5 & Kode Jenis Obat \\
\hline nama_jenis_obat & Text & 10 & Nama Jenis Obat \\
\hline
\end{tabular}

Table Name = MsKaryawan

Primary Key = kode_karyawan

\begin{tabular}{llll}
\hline \multicolumn{1}{c}{ Field Name } & \multicolumn{1}{c}{ Data Type } & \multicolumn{1}{c}{ Field Size } & \multicolumn{1}{c}{ Keterangan } \\
\hline kode_karyawan & Text & 5 & Kode Karyawan \\
\hline nama_karyawan & Text & 50 & Nama Karyawan \\
\hline tanggal_lahir_karyawan & Date/Time & Medium Date & Tanggal Lahir \\
\hline
\end{tabular}




\begin{tabular}{llll}
\hline & & & Karyawan \\
\hline alamat_karyawan & Text & 100 & Alamat Karyawan \\
\hline telepon_karyawan & Text & 20 & Telepon Karyawan \\
\hline email_karyawan & Text & 50 & Email Karyawan \\
\hline password & Text & 6 & Password \\
\hline
\end{tabular}

Table Name $=$ MsPelanggan

Primary Key = kode_pelanggan

\begin{tabular}{llll}
\multicolumn{1}{c}{ Field Name } & \multicolumn{1}{c}{ Data Type } & Field Size & \multicolumn{1}{c}{ Keterangan } \\
\hline kode_pelanggan & Text & 5 & Kode Pelanggan \\
\hline nama_pelanggan & Text & 50 & Nama Pelanggan \\
\hline alamat_pelanggan & Text & 100 & Alamat Pelanggan \\
\hline telepon_pelanggan & Text & 20 & Telepon Pelanggan \\
\hline
\end{tabular}

Table Name $\quad=$ TrResep

Primary Key = kode_resep

\begin{tabular}{llll}
\hline \multicolumn{1}{c}{ Field Name } & \multicolumn{1}{c}{ Data Type } & \multicolumn{1}{c}{ Field Size } & \multicolumn{1}{c}{ Keterangan } \\
\hline kode_resep & Text & 5 & Kode Resep \\
\hline tanggal_resep & Date/Time & Short Date & Tanggal Resep \\
\hline nama_pasien & Text & 50 & Nama Pasien \\
\hline
\end{tabular}

$\begin{array}{ll}\text { Table Name } & =\text { TrPemesanan } \\ \text { Primary Key } & =\text { kode_pemesanan }\end{array}$

\begin{tabular}{llll}
\multicolumn{1}{c}{ Field Name } & \multicolumn{1}{c}{ Data Type } & \multicolumn{1}{c}{ Field Size } & \multicolumn{1}{c}{ Keterangan } \\
\hline kode_pemesanan & Text & 5 & Kode Pemesanan \\
\hline tanggal_pemesanan & Date/Time & Long Date & Tanggal Pemesanan \\
\hline kode_pelanggan & Text & 5 & Kode Pelanggan \\
\hline kode_karyawan & Text & 5 & Kode Karyawan \\
\hline
\end{tabular}

$\begin{aligned} \text { Table Name } & =\text { TrDetailPemesanan } \\ \text { Primary Key } & =\text { kode_pemesanan } \\ & \text { kode_obat }\end{aligned}$

\begin{tabular}{|c|c|c|c|}
\hline Field Name & Data Type & Field Size & Keterangan \\
\hline kode_pemesanan & Text & 5 & Kode Pemesanan \\
\hline kode_obat & Text & 5 & Kode Obat \\
\hline kode_resep & Text & 5 & Kode Resep \\
\hline jumlah & Number & Long Integer & Jumlah \\
\hline
\end{tabular}

Table Name $=$ TrPenjualan

Primary Key = kode_penjualan

\begin{tabular}{llll}
\hline \multicolumn{1}{c}{ Field Name } & \multicolumn{1}{c}{ Data Type } & \multicolumn{1}{c}{ Field Size } & \multicolumn{1}{c}{ Keterangan } \\
\hline kode_penjualan & Text & 5 & Kode Penjualan \\
\hline tanggal_penjualan & Date/Time & Long Date & Tanggal Penjualan \\
\hline kode_pemesanan & Text & 5 & Kode Pemesanan \\
\hline
\end{tabular}

Beberapa rancangan layar ditampilkan pada Gambar 8 - 18. 


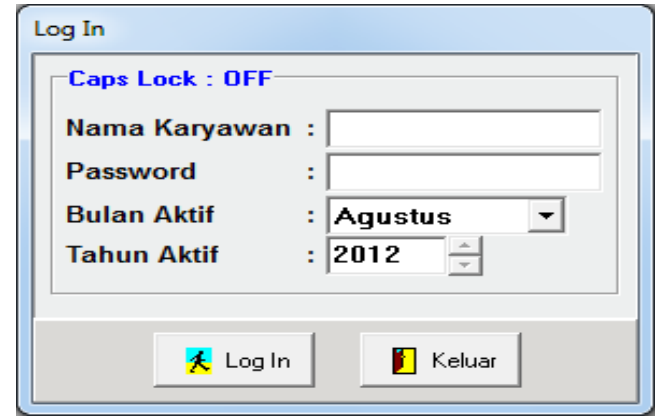

Gambar 8 Log In

\begin{tabular}{|c|c|c|c|c|c|c|c|c|c|}
\hline \multicolumn{10}{|c|}{ Master Jenis } \\
\hline $\begin{array}{c}\square \\
\text { Baru }\end{array}$ & $\begin{array}{l}\text { 场 } \\
\text { Ubah }\end{array}$ & 14 & 4 & - & M & $\begin{array}{l}\text { 輀 } \\
\text { Hapus }\end{array}$ & $\underset{\text { Cetak }}{\stackrel{\text { 是 }}{2}}$ & 㝵 & $\underset{\text { Tutup }}{\mathbf{9}}$ \\
\hline Jenis & \multicolumn{3}{|c|}{ KAPSUL } & & & & & \multicolumn{2}{|l|}{$x$} \\
\hline \multicolumn{2}{|c|}{ Jumlah Jenis : } & & & & & & & \multicolumn{2}{|c|}{ ]) harus diisi } \\
\hline
\end{tabular}

Gambar 10 Master Jenis Obat.

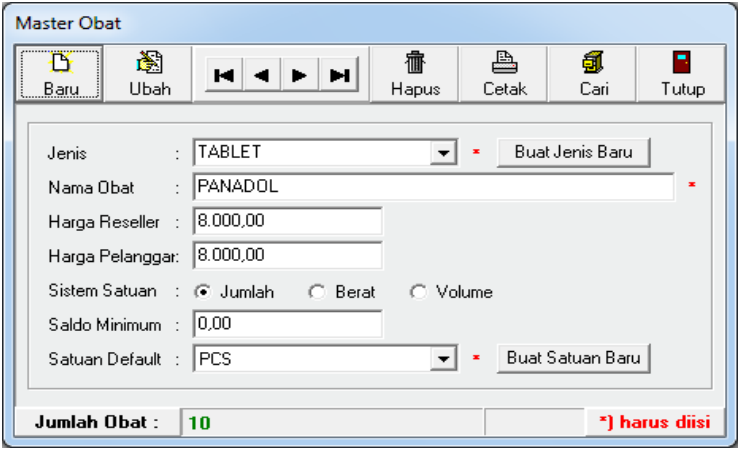

Gambar 9 Master Obat.

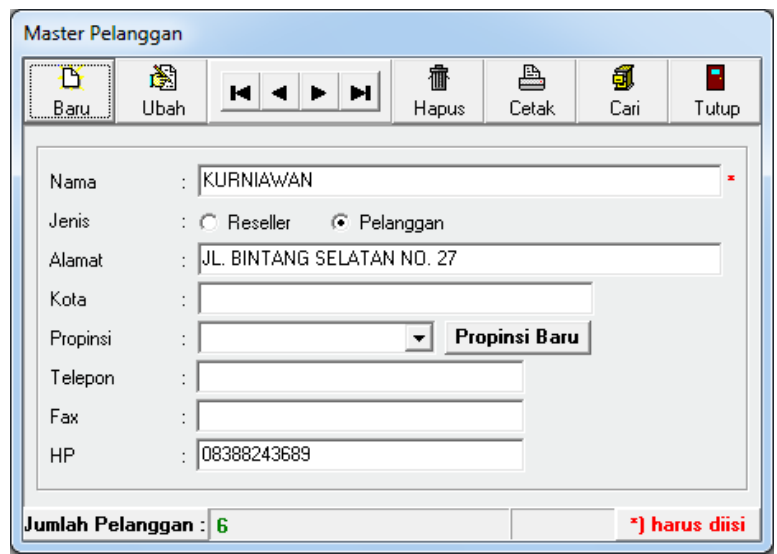

Gambar 12 Master Pelanggan.

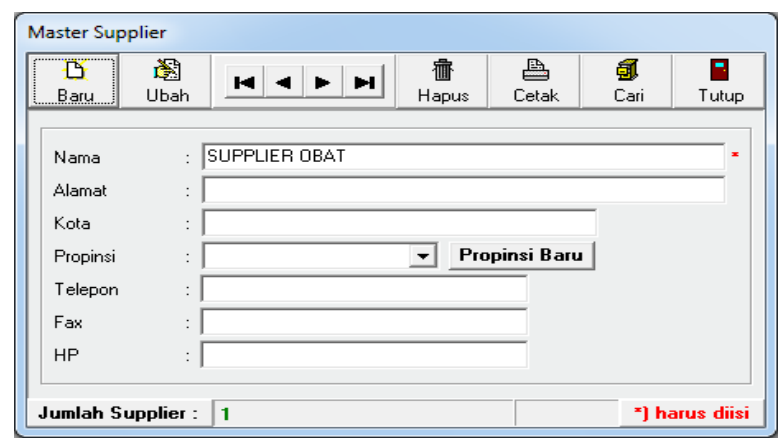

Gambar 11 Master Supplier. 


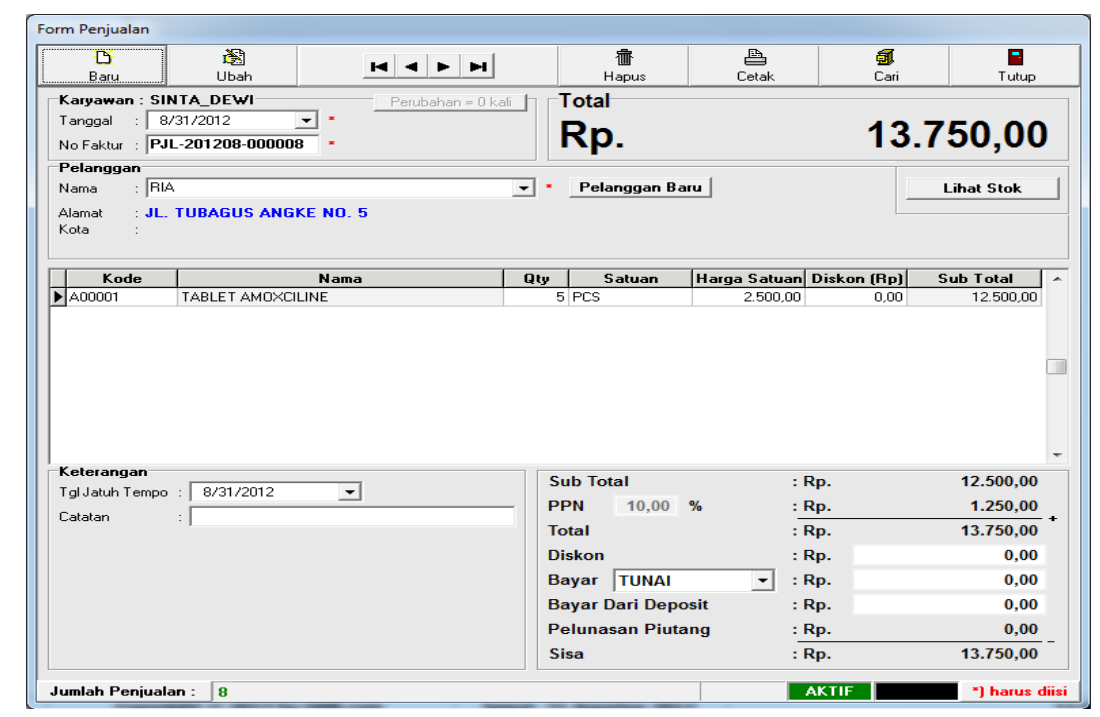

Gambar 13 Form Penjualan.

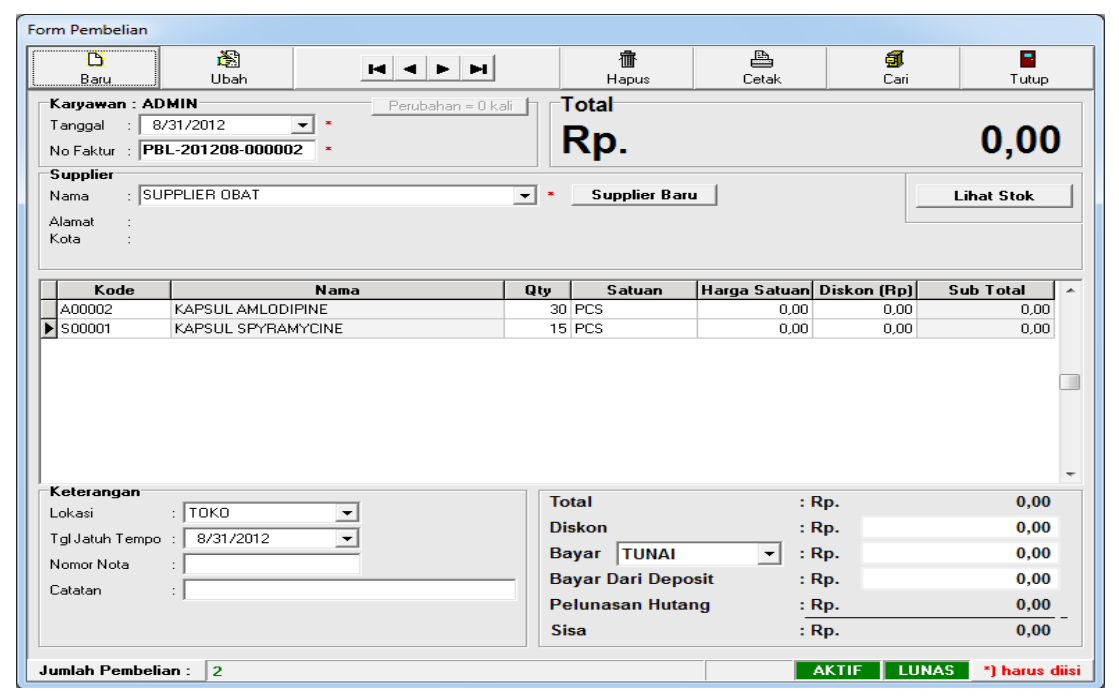

Gambar 14 Form Pembelian.

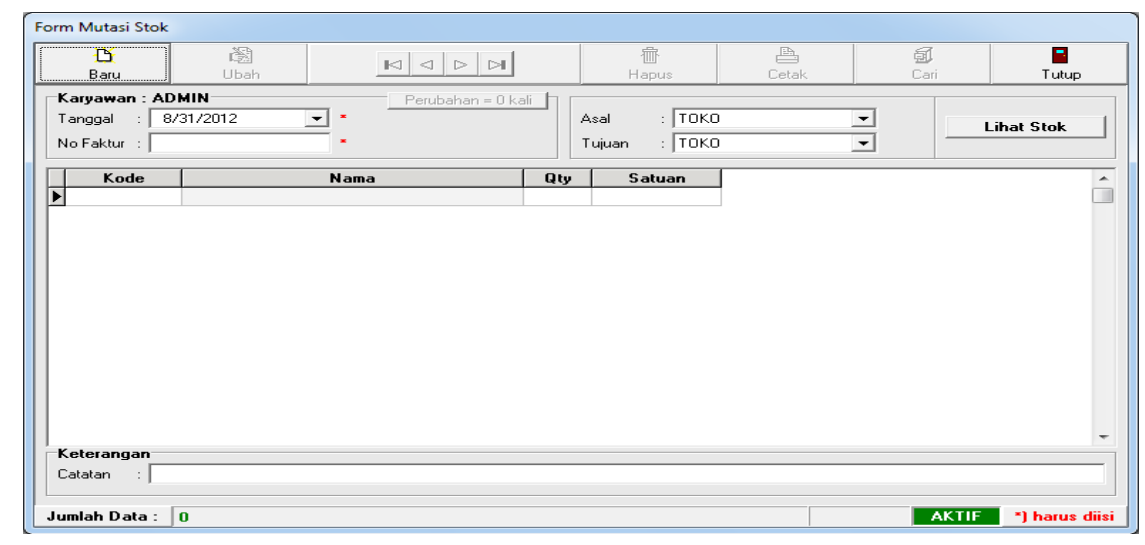

Gambar 15 Mutasi Stok. 
LAPORAN PENJUALAN

Periode : Agustus 2012

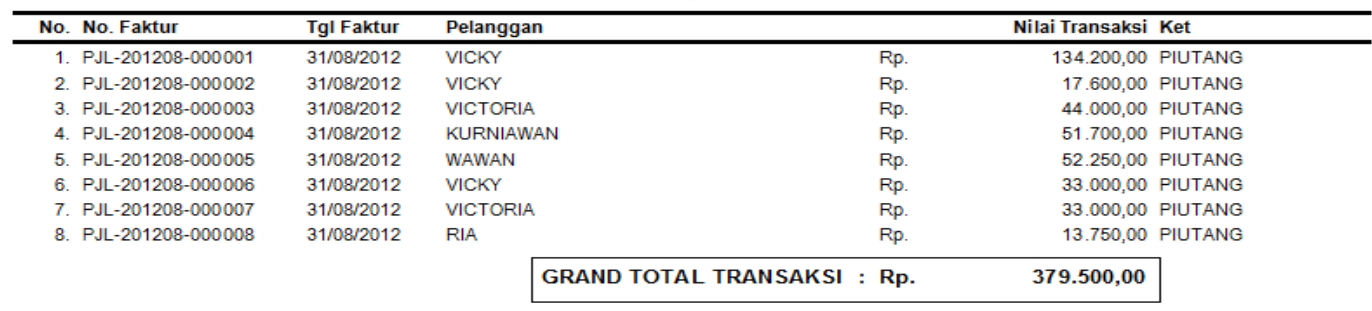

Gambar 16 Laporan Penjualan.

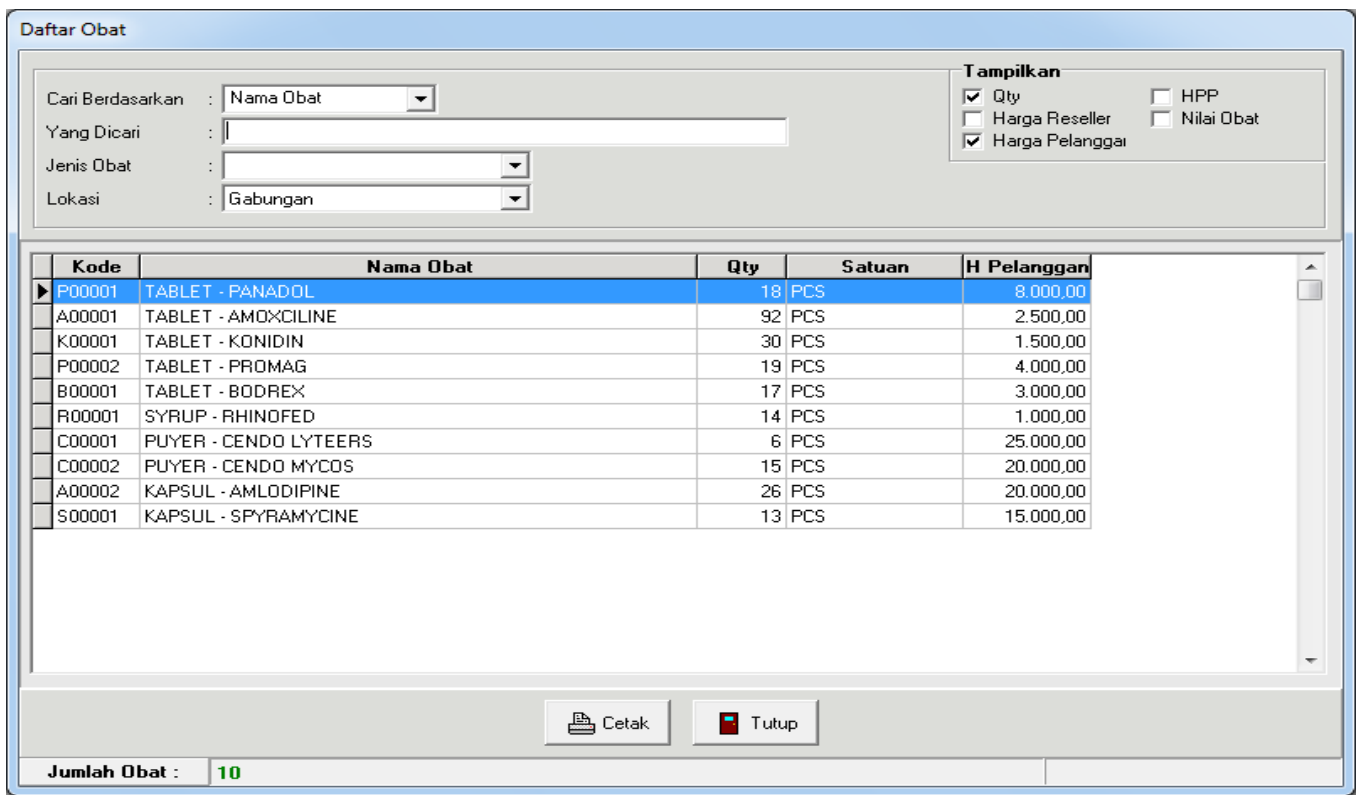

Gambar 17 Laporan Stok Obat Akhir.

KARTU STOK OBAT

Periode : Agustus 2012

Lokasi Obat : TOKO

\begin{tabular}{|c|c|c|c|}
\hline $\begin{array}{l}\text { 1. Nama Obat } \\
\text { Saldo Awal } \\
\text { Satuan }\end{array}$ & $\begin{array}{l}: \text { KAPSUL - AMLODIPINE } \\
: 0 \\
: \text { PCS }\end{array}$ & & \\
\hline No. Tgl Transaksi & Uraian & Qty & Saldo Akhir \\
\hline 1. $31 / 08 / 2012$ & Beli dari SUPPLIER OBAT (PBL-201208-000002) & 30,00 & 30,00 \\
\hline 2. $31 / 08 / 2012$ & Jual ke KURNIAWAN (PJL-201208-000004) & $-2,00$ & 28,00 \\
\hline \multirow[t]{2}{*}{ 3. $31 / 08 / 2012$} & Jual ke WAWAN (PJL-201208-000005) & $-2,00$ & 26,00 \\
\hline & Saldo Akhir & 26,00 & \\
\hline $\begin{array}{l}\text { 2. Nama Obat } \\
\text { Saldo Awal } \\
\text { Satuan }\end{array}$ & $\begin{array}{l}\text { KAPSUL - SPYRAMYCINE } \\
: 0 \\
: \text { PCS }\end{array}$ & & \\
\hline No. Tgl Transaksi & Uraian & Qty & Saldo Akhir \\
\hline 1. $31 / 08 / 2012$ & Beli dari SUPPLIER OBAT (PBL-201208-000002) & 15,00 & 15,00 \\
\hline 2. $31 / 08 / 2012$ & Jual ke VICKY (PJL-201208-000006) & $-2,00$ & 13,00 \\
\hline
\end{tabular}

Gambar 18 Kartu Stok Obat. 


\section{PENUTUP}

Berdasarkan hasil analisis dan perancangan sistem informasi akuntansi penjualan pada apotek, dapat disimpulkan bahwa proses pencatatan penjualan yang dilakukan di apotek masih dilakukan secara manual, sehingga sering terjadi perbedaan antara jumlah uang kas yang diterima dengan tagihan obat. Selain itu, pencatatan dan penyimpanan tagihan obat yang masih manual memungkinkan rusak maupun hilangnya nota sehingga back up untuk melakukan cross check penjualan terhambat. Oleh karena itu, sistem informasi penjualan yang diusulkan menyediakan fasilitas database yang dapat mencatat dan menyimpan setiap data tagihan atau transaksi obat secara terkomputerisasi dengan fitur yang dapat mempermudah proses pencarian data serta dapat memberikan informasi penjualan yang akurat, reliable, dan up-to-date.

Saran yang dapat diberikan adalah yaitu sebelum sistem diimplementasikan pada apotek, perlu diadakan pelatihan bagi user secara menyeluruh untuk dapat menggunakan sistem dengan baik. User harus dapat memahami cara menggunakan sistem dengan baik dan benar dalam rangka menunjang keberhasilan implementasi sistem di perusahaan. Disamping itu, perlu dilakukan maintenance terhadap sistem informasi penjualan selama penggunaan sistem tersebut melalui evaluasi secara periodik pada sistem yang sudah diimplementasikan dan dukungan bagi perubahan sistem jika diperlukan.

\section{DAFTAR PUSTAKA}

Laudon, Kenneth C., dan Laudon, Jane P. (2004). Management Information Systems. New Jersey: Prentice Hall.

McLeod, Raymond Jr. (2001). Sistem Informasi Manajemen (edisi 7), Hendra Teguh (Terj). Jakarta: Prehallindo.

Warren, Carl S., Reeve, James M., Fess, Philip E. (2005). Accounting (21th edition). Boston: SouthWestern college publishing.

Whitten, Jeffrey L., Bentley, Lonnie D., \& Ditman, Kevin C. (2000). System Analysis and Design Methods (5th edition). New York: McGraw-Hill. 